\title{
Reforming the WTO: the decision-making triangle revisited
}

\author{
MANFRED ELSIG AND THOMAS COTTIER
}

\section{Introduction}

Are international organisations (IOs) back in vogue? While most IOs were treated badly for most of the cold war period, they have recently attracted more attention, raising expectations in many policy areas in international law and global politics. Some organisations, in particular the World Trade Organization (WTO) clearly moved centre stage during the Uruguay Round (1986-94). Ever since then, increasing pressures emanating from globalisation processes have steadily improved the prospects for IOs to be chosen to manage and coordinate emerging challenges. Growing needs to address global concerns call for enhanced cooperation, if not advanced integration of policy areas at the international level. The existing constitutional framework of IOs, essentially shaped after the Second World War, for want of a better alternative, has to serve as the backbone for taking additional steps in identifying and shaping public goods, rights and obligations of states and private actors. In the wake of financial crises, the challenges of ongoing climate change and new pandemic threats, calls for delegating more tasks to IOs have intensified. Yet most of the unfolding potential is far from being utilised. International cooperation still hinges on the reluctance of key actors to delegate sufficient authority to the supranational level and to address appropriate structures and processes of decision-making commensurate with the tasks ahead. Traditional perceptions of sovereignty of the nation state loom large.

The WTO is not immune to these developments in world politics. The creation of the organisation was assisted by a constitutional moment of a liberal nature and the strong sponsorship of the transatlantic partners after the end of the cold war. In recent years, a re-emerging interest in protectionist measures, the slowing down of the liberalisation 
momentum and growing calls to improve the development-friendliness of the system have proved a challenge to the functioning and the legitimacy of the WTO (Cottier 2010). While we continue to witness high expectations as to what the WTO as a negotiation forum can achieve and deliver, the slow progress in the Doha Round negotiations and the scaling down of ambitions over the course of the negotiations indicate the lack of adequate systemic capacity to respond to the challenges, although it should be stressed that most of the problems rely upon substantive issues and divergences. Yet, looking into the future and at the new challenges on the table, it is evident that the existing structures will face great difficulties in coping adequately; the structure-substance pairings no longer match (Cottier 2010; Steger 2010). Thus, the story of current and future WTO performance needs to be read in conjunction with an assessment of the decision-making machinery (Gutner and Thompson 2008; Elsig 2009a). Judging from the outcomes over the last fifteen years, its performance does not look terribly impressive.

While IOs have again moved into the spotlight of contemporary politics, the decision-making procedures negotiated under the post Second World War Pax Americana and subsequent conventions and practices have in most cases changed little over time. By and large, decision-making is dominated by consensus diplomacy. Progress has essentially been limited to the regional level, in particular within the European Union, which has achieved a notable sequence of reforms to decision-making over time. In global institutions, governance rules which are designed at the stage of creation suffer from a type of 'multidecision trap'. Actors learn to accommodate to the existing rules and usually exhibit strong reluctance to engage in discussions on treaty reform. They are risk-averse as far as experiments with new modes of decision-making are concerned. In addition, there are many veto players that expect to lose from a governance reform. This leads to a type of decision-making trap from which it is hard to escape. The formal (and informal) rules on how the WTO takes decisions in treaty-making have changed little since the 1950s, whereas the number of participants and the difficulties in finding consensual solutions have increased. By contrast, the judicial arm of the GATT/WTO underwent substantial reform during the Uruguay Round (UR), introducing a two-tier system which is essentially based upon majority ruling and the exclusion of veto powers. ${ }^{1}$ Finally, decision-making is further hampered by the existing cleavage of

1 This legalisation leap still remains rather a puzzle in the international relations literature. 
political and judicial avenues within the organisation (Cottier 2007; Cottier and Takenoshita 2008). Thus the WTO, like many other IOs, is confronted with a double challenge: how to address new challenges from globalisation and how to reshape decision rules. This chapter discusses the latter, focusing on the current system and suggesting experimentation with new forms of decision-making.

The chapter is structured as follows. First, it reviews the current decision-making triangle in the WTO, highlights systemic weaknesses and posits that the current system is inadequate in the long run. Second, it outlines key elements for a redesign and engages in a counterfactual exercise as to the results of reform.

\section{The Current Decision-Making Triangle}

The current decision-making system related to treaty-making combines three elements: the dominance of contracting parties, the consensus principle and the logic of the single undertaking (Elsig 2010a). Below, we critically discuss this decision-making triangle before arguing why it will prove unsustainable in the long term. Figure 13.1 maps the elements of the existing triangle.

\section{Member-driven}

While most IOs can be labelled member-driven, there is substantial variance between them. The WTO scores high on this element, in particular

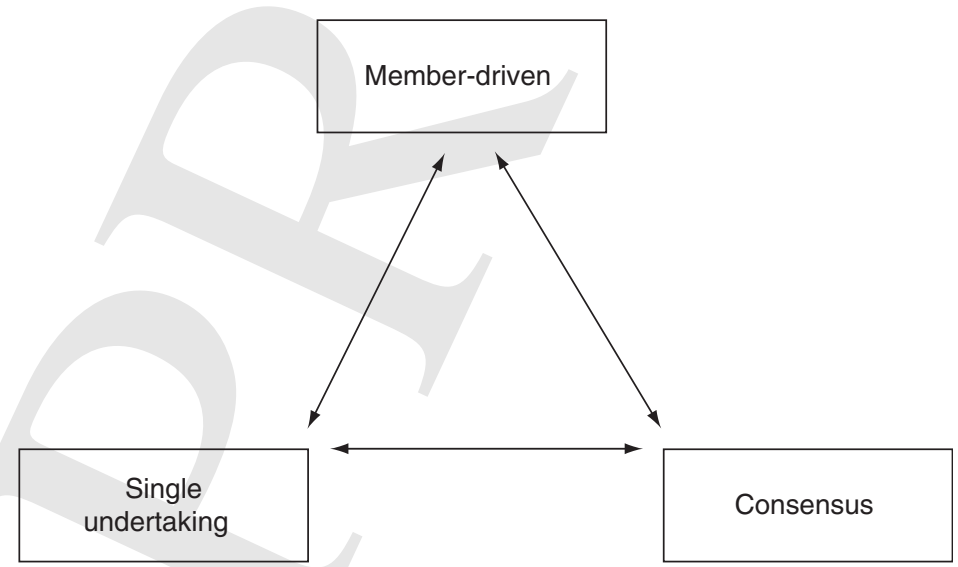

Figure 13.1 The incompatible triangle 
in the legislative process of the WTO (on negotiations, see Elsig 2009a, 2010a). The contracting parties are dominating the rule-making process. This amounts to one of the basic dogmas and beliefs of the system (Jackson 2001). Every negotiating group has a chairperson who is selected from representatives of the contracting parties based in Geneva. The influence of the chair is a function of his or her resources and knowledge, but is also linked to decision procedures and the politicisation of the issue at stake (Odell 2005; Elsig 2010b). Due to the length of negotiations, committee chairs usually rotate during the course of a round. ${ }^{2}$ WTO staffers act merely as assistants to the chair of the various negotiation groups. The Director-General (D-G) is the only actor from the WTO (understood in the narrow sense of an IO) who has some discretion and assigned powers, albeit limited ones. The post of Director-General is the only supranational chair and needs to be distinguished from elected or rotating chairs within the organisation (Tallberg 2010). The D-G chairs the Trade Negotiation Committee (TNC) ${ }^{3}$ meetings, consults informally with members and is at times invited to the small group negotiations among the leading contracting parties. The D-G also organises, jointly with the representatives of the hosting governments, the Ministerial meetings that usually take place at two-yearly intervals. ${ }^{4}$ Yet, the D-G has no formal agenda-setting powers and works under the guidance of the members who define the outer limits of the D-G's autonomy.

While the GATT/WTO system has always been characterised by a strong dominance of Geneva-based and (in the case of some contracting parties) capital-based trade diplomats, existing evidence suggests that the formal and informal role of the D-G and the WTO staff in negotiations has partially decreased, in particular since the Tokyo Round negotiations (Winham 1986; Elsig 2010b). In past trade rounds, WTO staffers were more prominently involved in the drafting of texts and on various occasions were asked by contracting parties to chair negotiation groups to bring about convergence of positions and provide for linkages to create workable solutions (Croome 1995). This type of Secretariat support is largely absent today. Put differently, delegation to the most obvious supranational chair representing systemic interests (the D-G and the Secretariat) is not occurring (Elsig 2010b).

\footnotetext{
2 Representatives of big powers seldom serve as chairs.

3 The TNC has been created for the negotiation round. It is formally under the authority of the General Council which is the main decision-making body in day-to-day work of the WTO. The highest authority is the Ministerial Conference.

4 There was no Ministerial meeting in 2007.
} 
Whereas the WTO operates with constituted bodies for decisionmaking, such as the Ministerial Conference and the General Council as well as other councils and committees, it lacks a formal executive steering body as exists in most other IOs. Decision-making is mainly shaped by informal and ad hoc processes. Although the creation of a delegated steering body (executive council) was discussed during the ITO negotiations and an executive committee was proposed in the Havana charter, it never saw the light of day (Xu Yi-chong and Weller 2004). During the GATT times, the idea was again revived as members created a consultative group (the G18) in 1975 that was active until the UR picked up speed. The group was chaired by the D-G and included full and alternate members, the difference being that while the latter had only one seat at the table, the full members were allocated two seats. The group's objectives were to provide overall guidance and to serve as an important forum of debate. The exclusive group met at regular intervals and consisted mainly of high officials (Xu Yi-chong and Weller 2004: 804). While the group was useful for recommending ways forward, it lacked any formal decision-making power. The members of the group met between two and four times a year (Blackhurst 1998: 33-5). Once the G18 stopped meeting in 1987, other informal groups partially took over its role, such as the de la Paix Group (composed of ambassadors) during the UR negotiations. In the current round, various green room settings play a similar role to that of the G18; however, all groups that have followed in the footsteps of the G18 have been less institutionalised. ${ }^{5}$

As to the factors that explain member dominance and reluctance to design new forms of delegation, three stand out. First, increased legalisation (and bindingness) of international trade law following the UR negotiations has led many actors to pay more attention to the WTO (Goldstein and Martin 2000). Actors have adjusted to the new system, where a type of international court (with the Appellate Body at its top) upholds or rejects findings of expert panels. These rulings at the appeal stage cannot be blocked by the litigating parties and create systemic pressures to implement domestically. The Appellate Body has also used its delegated discretion in ways not always envisaged by contracting parties (Van den Bossche 2006). As a consequence of an increased impact of dispute settlement outcomes, negotiations are attracting wider interest and negotiators are attempting to write more complete

\footnotetext{
5 The green room is an expression for meetings comprising 20 to 40 delegations in an informal setting.
} 


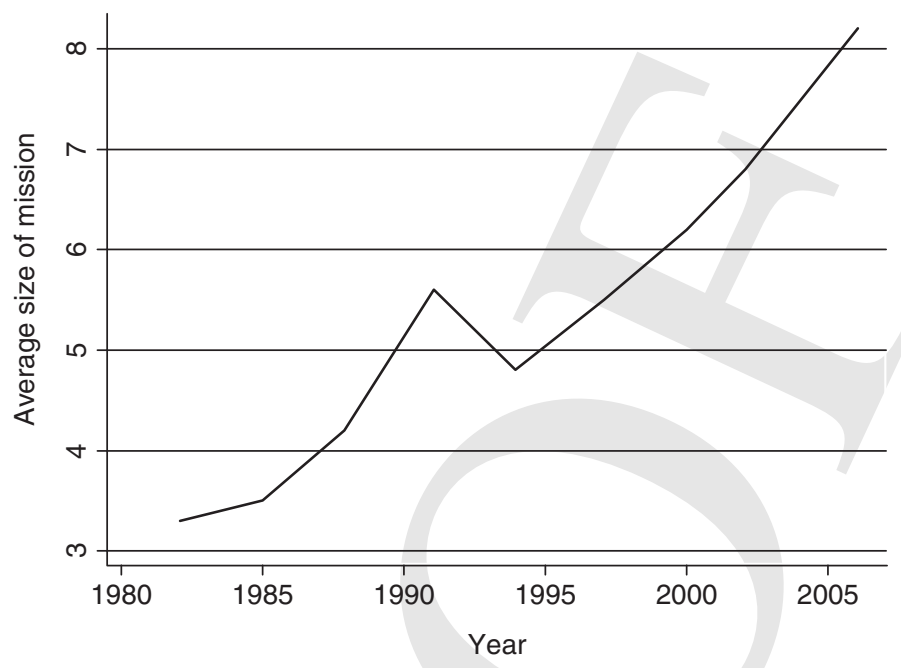

Figure 13.2 Missions' scaling up

Note: coded from 1982 every three years, no blue book available for 2003.

Source: WTO blue books, own calculations.

contracts that will reduce the legal bodies' scope for interpretation. Less reliance on ambiguous treaty text automatically prolongs the negotiation process, while reluctance to ask other actors (an elected board, the D-G or the Secretariat) to take a more active stance increases. Moreover, as theorised by James Fearon, the WTO is a good example of how negotiations become more cumbersome and lengthy as participants internalise the long shadow of cooperation with important distributional effects (Fearon 1998). Negotiators bargain hard knowing that the outcomes will last for quite some time and be difficult to modify in the not so distant future. Overall attention paid to the WTO by its members is reflected in the number of trade diplomats based in Geneva. The total number of accredited trade officials rose from 233 in 1982 to 769 in $2006 .{ }^{6}$ Figure 13.2 indicates the growth of the average number of contracting parties' personnel dealing with WTO matters. The average number of trade diplomats prior to the launch of the UR was 3.3 per mission and had reached 8.2 in 2006. The data, however, also suggests

6 The growth of the WTO Secretariat is substantially lower during this period, rising from 43 to 118 . This number, however, overestimates the number of civil servants involved in negotiations (Elsig 2010b). 


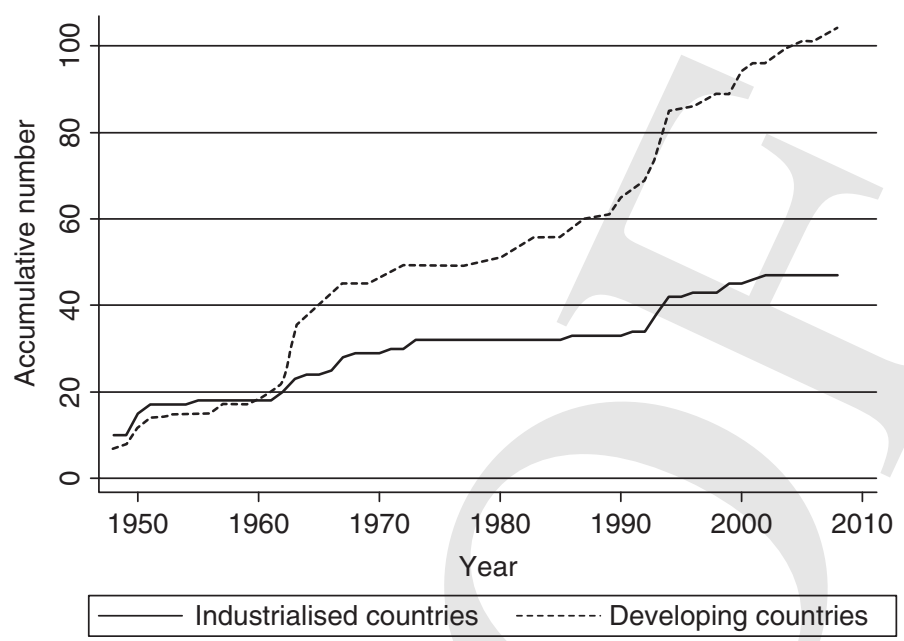

Figure 13.3 Membership of developing countries Note: Defined according to the OECD classification. Source: WTO website, own calculations.

that after the completion of the UR, overall mission size decreased for some time before increasing again as a new trade round was prepared in the late 1990s.

Second, we have witnessed increasing interest by developing countries, which has been reflected by a surge of demands for accession to the GATT/WTO and more active participation in negotiations. Given growing export interests, these new voices have challenged transatlantic dominance and have called for developmental concerns to be taken up more prominently by the system. Developing countries are relying on various forms of coalitions, from broad ideological or geography-related to issue-based groups to empower themselves. ${ }^{7}$ However, participation has not been limited to existing or emerging new powers from the South; smaller actors have also started to engage in the multilateral rule-making system. Representatives of smaller developing countries have become more active in negotiations as witnessed by the Cotton- 4 initiative. ${ }^{8}$ Figure 13.3 illustrates the increase in developing countries' membership over time; in particular many advanced developing countries have joined since the end of the 1980s.

7 On coalitions, see Narlikar 2003.

8 Sector initiative by Benin, Burkina Faso, Chad and Mali to address cotton subsidies. 
In light of the difficulties for many developing countries in raising their voice and participating actively in other global economic multilaterals (e.g., the IMF and the World Bank), they have few incentives to delegate their newly discovered prerogatives within the WTO to an elected board or to the D-G and the Secretariat.

Third, the lack of incentives for Geneva-based negotiators to yield power to the Secretariat also relates to existing material and ideational factors (Elsig 2010b). Geneva-based trade diplomats have little to gain from an act of delegation to the Secretariat as their positions as masters of the negotiations will be constrained (at least in the short term). Furthermore, many contracting parties are concerned about an alleged in-built agenda of liberalisation which is supported by the Secretariat (Elsig 2010b).

\section{Consensus principle}

The consensus principle is a fine illustration of how norms have become internalised in the WTO through practice despite the GATT and the WTO formally envisaging the recourse to different majority voting thresholds on the basis of one state, one vote (Ehlermann and Ehring 2004; Footer 2006; Steger and Shpilkovskaya 2010). The consensus principle has become accepted among diplomats as the prime mode of decision-making to the degree of being 'taken-for-granted', the final stage of a norm cycle (Finnemore and Sikkink 1998). This was also reiterated during the UR negotiations. Article IX of the Marrakesh Agreement Establishing the WTO states: 'The WTO shall continue the practice of decision-making by consensus followed under GATT 1947'. A footnote to the provision defines consensus as follows: 'The body concerned shall be deemed to have decided by consensus on a matter submitted for its consideration, if no Member, present at the meeting when the decision is taken, formally objects to the proposed decision'. In the WTO, consensus thus applies among members present in the room at both formal and informal meetings. ${ }^{9}$ Actors over time have internalised consensus as the most appropriate rule given the organisational context. There is ample anecdotal evidence as to the power of discursive practices driven to a large extent by a logic of

\footnotetext{
${ }^{9}$ Unlike affirmation, it does not require active support of a proposal, but is limited to the absence of rejection and opposition. Acquiescence amounts to the predominant factor in the operation of consensus.
} 
appropriateness. Put differently, behaviour follows social rules defined by what is conceived as right, natural and expected by the political community actors are part of. ${ }^{10}$ It even applies to housekeeping matters in the organisation. In the process of selection of the D-G in 1999, when there was a clear deadlock over the candidates' appointment, two delegations were requesting a vote. In reaction to this demand, one party put up its flag and stressed that 'in this organization we don't vote'. This was followed by strong supporting statements by the overwhelming majority of members. ${ }^{11}$

Such support has two major roots. First, consensus is felt to express and guarantee sovereign equality of members. The principle is often portrayed as the most democratic form of decision-making. This is related to the argument that states have to give consent to international agreements to be bound. All members formally enjoy the possibility of opposing and blocking decisions single-handed. It appears to convey power. Second, the imbalance of economic and political clout of members and the principle of one state, one vote renders the application of voting virtually impossible without endangering the organisation (Cottier and Takenoshita 2003). Outvoted powerful members may choose explicit or implicit emigration and turn to exclusively shaping trade relations unilaterally or through bilateral or regional agreements.

Yet, while the consensus principle enjoys quasi-universal support within the system, it could be labelled as a form of 'managed hypocrisy'. The idea of consensus produces a false feeling of equal participation and leads to frequent frustration among many parties as they are excluded from decision-making in small group negotiations. The small group participation has been defined by the supplier principle and more recently by the sheer economic power of a party to the WTO agreements (Wilkinson 2009). Over the years, the GATT/WTO has gradually moved from a bipolar-dominated to a multipolar system. It is de facto characterised by a set of concentric circles where the inner circle is dominant and predefines the potential win-sets (Putnam 1988). The member composition of this circle varies slightly in relation to the issues at

10 The logic of appropriateness needs to be interpreted in relation to the logic of consequences which attributes to actors an active rational behaviour, weighing different options and strongly valuing the personal utility of potential outcomes (March and Olson 2009).

${ }^{11}$ Interview, 12 July 2006, Senior WTO trade official. 
stake. ${ }^{12}$ As we move outwards towards larger decision-making bodies (from green room to Heads of Delegation meetings), deliberations are characterised by 'testing' the likelihood of acceptance of potential small group outcomes. ${ }^{13}$ This signalling game precedes the so-called 'multilateralisation' process occurring towards the end of negotiations to bring everyone on board. In practical terms, consensus amounts to a system of decision-making reflecting strong differences in power and what is in fact a highly uneven distribution of voting powers. Such findings call into question the contribution of consensus to the democratic legitimacy of IOs (Cottier 2009). ${ }^{14}$

Consensus is one element among many (Grant and Keohane 2005; Elsig 2007). As shown above, in a consensus system, some clearly are more equal than others while conveying the illusion of equality. Consensus can lead to unintended effects at the domestic level weakening governments' positions vis-à-vis particular interest groups among their constituencies. Governments often face a dilemma. While an overall trade deal might benefit the economy as a whole, the formal veto power invites domestic opposition at home to call for negotiations to be blocked in the pursuit of sectoral interests. Put differently, a government that faces well-organised domestic groups is under constant pressure to use its veto powers on specific issues. If a government ignores some of these calls, it will have to explain to its constituencies, at high political costs, that blocking negotiations in a particular sector is incompatible with overall interests in the multilateral trading system and the support for other sectors, in particular its export industries. As a result, governments opt more often than necessary for accommodating the calls of vested interests. This undermines not only their credibility at home (beyond successful rent-seeking groups), but also affects the governments' position at the WTO, as trade diplomats are called upon to explain why they engage in hypocritical and tactical conduct. The option to fight and lose a battle in a democratic vote in a transparent manner,

${ }^{12}$ In the current Doha negotiations, the key group includes the US, the EU, India and Brazil (G4). Depending on the issues at stake this group is extended to include the participation of Japan (G5), Japan and Australia (G6) and more frequently China.

13 The Heads of Delegation meeting is an informal meeting where all contracting parties can participate.

${ }^{14}$ Some argue that IOs cannot be democratic as they are composed of various types of countries with different democratic and non-democratic political systems (Dahl 1999). Such a conceptualisation makes a differentiation between the international and the regional/national level and calls into question the application of domestically accepted governance models to the international system. 
organised along accepted principles of majority voting dominating constitutional processes, is not available.

Finally, consensus creates considerable imbalances with the system of dispute settlement which no longer operates on the same principle of blocking powers (Barfield 2001). While dispute settlement decisions proceed on the basis of excluding losing parties from consensus and can only be blocked by consensus of all members, legislative response to rulings remains virtually impossible in between trade rounds. This, in turn, exposes various panels and in particular the $\mathrm{AB}$ to taking the lead in further developing the trading system, creating additional tensions and strains within the system.

\section{Single undertaking}

Single undertaking was an invention of the UR. Towards the end of the negotiations, the US and the EU were pushing for a package deal without notable exceptions. This was largely based on a shared perception that the Tokyo Round agreements, with optional adherence to the newly created codes, allowed for free-riding and thus weakened the system overall and left out developing countries from serious commitments and thus also from being taken seriously. The Tokyo Round further developed GATT disciplines, but these legal developments only applied to a limited number of contracting parties. It failed to truly integrate developing countries and left them largely outside the process of building the multilateral trading system. This constellation created asymmetries which the unilateral application of most-favoured nation (MFN) treatment could not remedy in a satisfactory manner. Treaty relations based upon GATT resulted in asymmetric rights and obligations. ${ }^{15}$ The US and the EU thus pressed for a treaty that all parties had to accept in its entirety. Developing countries were granted longer periods of implementation while special and differential treatment $(\mathrm{S} \& \mathrm{D})$, in terms of substantive rights and obligations, remained marginal and largely ineffective (Cottier 2006). In addition, pre-existing and revised GATT agreements were incorporated into the new WTO legal framework, but did not apply to those members that abstained from joining the newly created organisation (Steinberg 2002). This transatlantic 'go-it-alone power' demonstration left other parties no choice but to accept the new

${ }^{15}$ In addition, important incentives to legal restructuring were lacking in developing countries, often increasing gaps between developing and industrialised countries rather than closing them. 
treaties (Gruber 2000). It is only with respect to a few sectoral agreements that members retained the right to abstain, such as in government procurement. ${ }^{16}$

The current trade round started with parties agreeing on a single undertaking approach. Parties strongly advocated the negotiation logic that 'nothing is agreed until everything is agreed'. This was one of the lessons learned from the UR negotiations. While the single undertaking worked in the UR to produce a significant outcome, it seems that actors have now adjusted to the logics of a single undertaking project. Single undertaking is no longer a comparable driving factor providing negotiations with much needed linkages. VanGrasstek and Sauvé observe that 'paradoxically, instead of encouraging bold deals by causing each country to focus on those parts of the package that they most dearly desire, the single undertaking might promote timidity by causing each country to focus on those things that they most fear' (2006: 858). ${ }^{17}$ The reason for this timidity is not only a question of fear, but a type of inherent negotiation logic among contracting parties that being a first-mover in terms of making a meaningful concession is seen as a disadvantage as subsequent pressures on the other parties to follow cannot be maintained (Elsig 2009b).

\section{Why it doesn't work}

The difficulties in reaching agreement and in concluding a trade round are manifold. Partly, they relate to the substance and partly to the design and modes of decision-making. In this chapter, we argue that the current triangle of decision-making is unsustainable in the long run. While the triangle worked for the UR negotiations, it has already shown its limits in the current round. The system has led to a sort of decision trap from which it is hard to escape. An obvious symptom of structural failure is that contracting parties are not moving towards final negotiations and face each other with a set of minor concessions and major demands over the long negotiation cycle. ${ }^{18}$ The problem has also been identified as an adjusted version of 'endless-cycling' (Elsig 2010a).

16 However, it needs to be noted that the commitments in the second pillar of the WTO (General Agreement on Trade in Services - GATS) vary substantially.

17 An additional practical problem for negotiators relates to the assessment of benefits (and thus reciprocity) for concessions negotiated across issue areas.

18 When negotiations are stuck in Geneva, negotiators turn to high-level political fora (e.g., G7/G8 or G20) to provide the necessary impetus to allow for finding a zone of agreement. Evidence from this round suggests, however, that little momentum is produced from these types of Ministerial gatherings. 
Two important transformations will further expose the limits of the current system. First, the WTO has moved from a regime focusing predominantly on reciprocal lowering of tariffs to a regime addressing challenges beyond the classical border adjustment policies. The bulk of WTO negotiations today deal with non-tariff barriers in different regulatory areas, ranging from technical barriers to trade to subsidies, services and intellectual property. This is likely to increase further in the future. The WTO will be confronted with an increasing complexity of trade regulation entailing complex issues of trade and environment (climate change), investment and competition issues, or human rights and social standards. While the UR agreements were essentially about creating and reforming the system, with the Doha negotiations the system moves further towards addressing commitments on internal support and disciplines on domestic regulation within the existing framework. Future negotiations will be structurally even more complex than current ones. They not only include more issues relating to domestic regulation as opposed to market access, but increasingly they entail more interfacing with issues dealt with in other IOs (Chapter 9). The second transformation relates to the waning dominance of the transatlantic partners. The world has moved into a multipolar system with a multitude of key players (Chapter 6). The process of multilateralising bilateral deals can no longer be expected to work. More players are in fact in a position to exercise veto powers than before. The process therefore needs to be inclusive from the very beginning. All of this requires rethinking of decision-making processes and modes.

\section{Reforming the System}

\section{Incremental change?}

As to the question of whether modifying any of the three elements might suffice to break the decision-trap, we suggest some scepticism. Let us briefly look at the three potential combinations and engage in a type of contrafactual reasoning of expected results. ${ }^{19}$

Consensus and member-dominance (but issue-based). Scenario 1 relates to weakening the paradigm of the single undertaking, while leaving other elements of the triangle unchanged. A so-called issue-based approach

19 This exercise is inspired by the analogy to the 'inconsistency triangle' (or 'unholy trinity') widely discussed in relation to monetary policy choices. 
(with continued application of the consensus principle and member dominance) would lead to a system where only minor issues are addressed successfully. While some scholars argue that the opt-out clause on TRIPS and Public Health illustrates that the existing system can find workable solutions to issue-based problems, the empirical evidence of this (rare) case seems far from conclusive (Drezner 2007). Another type of issue-based approach is experimenting with variable geometry, in particular the idea of a critical mass approach to decision-making as sketched by the Warwick Commission (2007). ${ }^{20}$ Yet, as long as consensus applies to these initiatives (in the sense that they shall not affect the rights and obligations of parties not participating), little is to be expected to come out of this process (Elsig 2010a). Veto powers are plentiful and freeriding possibilities will not create sufficient incentives to ambitiously take up new concerns through such differentiated cooperation.

Consensus and single undertaking (but delegation). Scenario 2 foresees the strengthening of the supranational character of the organisation by allowing for additional delegation either to the D-G and the Secretariat; more powers to the chair; or the creation of a managing or executive board. Delegation would lead to a situation where much of the politics (informal negotiations) between contracting parties would be supplemented by the involvement of a supranational actor. This combination has the potential for speeding up the process as more delegation to a supranational actor assists in tackling agenda-setting problems and endless-cycling. However, as long as consensus and single undertaking prevail, the veto power of many contracting parties will make any conclusions difficult. Proposals by the Secretariat or the 'empowered' chair could be easily blocked and an executive board would have to settle for the lowest common denominator. ${ }^{21}$ Credible signals from veto players early in the process of making new rules will have a negative impact on the prospects of this scenario.

Member-dominance and single undertaking (but recourse to weighted voting). Scenario 3 might represent the most promising partial reform. However, it signifies probably the most controversial change as it departs from the practice of a well-established internalised norm and has no significant precedent in the GATT/WTO regime. On the positive side, moving towards forms of weighted voting (in case consensus fails) would

\footnotetext{
20 See also Low (2009).

21 There might be a different dynamic when the Executive Board meets at the Ministerial level (see next section).
} 
not change members' active involvement in the negotiation process. On the contrary, it could even increase participation as actors cannot fully anticipate whether they will end up as part of the majority (the winning coalition) or the minority (the losing coalition). Moreover, the dictum of the single undertaking would allow for the creation of additional opportunities through cross-linkages compensating members for being in the minority group on some issues. The overall success clearly depends on the willingness of those in the minority to accept policy outcomes supported by a large percentage of members. The increased input legitimacy (through participation) could to some degree address concerns of exclusion and increase acceptance (Elsig 2007).

\section{The reshaping of decision-making: looking beyond Doha}

The triangle has proved unsustainable in terms of producing tangible results. While adjustments to the existing system have been proposed (Warwick Commission 2007), incremental reform will not overcome the challenges illustrated by a brief counterfactual thought experiment. A more important far-reaching redesign is necessary. A reform of the system needs to address all three elements simultaneously, supported by a more streamlined decision-making system that allows the WTO to tackle the future problems related to global trade regulation.

The biggest obstacles are linked to the reluctance of members to cede control and to move away from the consensus principle. Yet, an orthodox reading of the Westphalian system turns out to be more of a myth than reality (Krasner 1999). ${ }^{22}$ Concerns over sovereignty in particular find manifestation in the positions of many emerging economies (in particular those that have recently gained international political and legal recognition). After years of playing second or third fiddle to the big trading powers, many developing countries have rediscovered the consensus-driven organisation and do not want to give up their newly acquired possibilities of using the veto power that consensus indirectly offers. However, it remains unclear whether veto power is equally distributed across the membership as argued above, and whether members dependent upon access to large markets can afford to use such powers. Final negotiations will most likely hamper efforts for the majority of

22 Moreover, it needs to be revisited under conditions of a multi-polar world where a transatlantic consensus is no longer in a position to carry the day (see Chapter 6 in this volume). 
contracting parties to effectively use veto power to advocate their vital interests.

A look at the most advanced IO in world politics, the EU, allows for some optimism that states can overcome existing obstacles to increased delegation over time. The EU has not been built in one day, and crises were used to further deepen integration. In the 1970s, the European Community suffered from integration fatigue and economic problems illustrated by the empty seat politics of French President De Gaulle and growing protectionism within the Community. Yet, the Community managed to overcome its stagnation. Over time the EU embarked on a set of constitutional reforms moving from consensus to qualified majority voting in many areas. ${ }^{23}$ The recent Reform Treaty turns to a system of a double majority on the basis of one state, one vote (55 per cent of members) and, in addition, a quorum of 65 per cent of the overall EU population. European integration was also driven by the supranational impetus from the European Commission (largely backed by the European Court of Justice), which had been granted some autonomy through agenda-setting prerogatives in decision-making (Alter 1998). Finally, the EU has moved over time from big package deals in Ministerial settings towards a more advanced system of decision-making with the objective of taking up policy issues as they evolve and need to be dealt with.

Below, we sketch five elements that need to be addressed simultaneously in order to engage in efforts at the reform of WTO decision-making (see Figure 13.4).

Strengthening the supranational character. A comparison with IOs of similar importance suggests a variety of delegation options. Various models could be envisaged ranging from allocating more discretion to chairpersons, strengthening the role of the WTO Secretariat and staff to creating an executive body. As argued above, the WTO suffers from an endless-cycling problem. It needs to overcome obstacles to allow it to move from the process of tabling proposals towards the true bargaining stage. In this respect, a growing membership has naturally increased the transaction costs of finding agreement. In addition, zones of agreement diminish with size of participants. Therefore, delegation to a supranational actor can potentially unblock the situation. A supranational actor can work as broker by setting a type of focal point in the form of tabling new treaty texts for discussion. This marks the end of a period of

23 This applies in particular to the first pillar of the EU. 


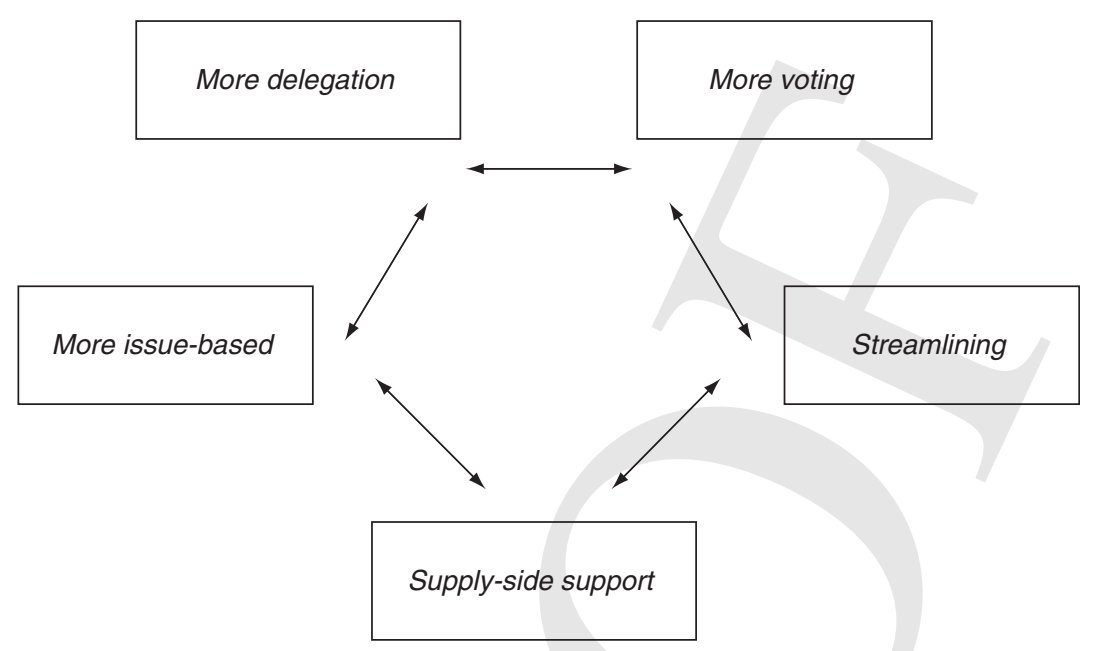

Figure 13.4 The new pentagon of decision-making

discussions and deliberations and leads actors towards the business of true negotiations.

Looking beyond negotiations, a way to strengthen the supranational character of the WTO is to give more powers to the D-G and to consider creating at least one of two types of executive boards. The first executive board could institutionalise the informal and ad hoc processes of green room negotiations. A new Consultative Body (CB) of Ambassadors under the chair of the Director-General would assume various functions in managing the organisation, namely appointing key personnel of the Secretariat, chairs of committees, and adopting budgetary allocations. It would also assume negotiating functions currently practised in the green room process, interfacing different negotiating agendas. Negotiating committees could call upon the $\mathrm{CB}$ to settle unresolved issues. The $\mathrm{CB}$ would report to the General Council and the Ministerial Meeting. The $\mathrm{CB}$ would attempt to reach consensus (in the shadow of voting), yet actual voting would only take place at a later stage (General Council or the Ministerial Meeting).

In addition to (or instead of) the $\mathrm{CB}$, one could consider the option of creating a Ministerial Board (MB) comprising ministers who would give overall guidance and could be called upon to move dossiers forward. The MB would meet regularly and take stock of the negotiation processes and the operation of the WTO. The lack of ministerial involvement in trade policy beyond Ministerial Meetings, thus merely in the concluding 
phases, may be an important factor in declining multilateralism. It is no surprise that ministers pay more attention to bilateral agreements where results can be directly influenced and achieved. Ministers have not developed ownership and stewardship of the organisation. They are not critically involved in shaping the agenda of the organisation, nor in the appointment of key personnel including the D-G and the Appellate Body. They do not feel responsible, and the task of moving the WTO forward falls heavily upon the shoulders of Geneva-based ambassadors and officials in national capitals. They are involved in defining the financial envelope of the organisation and its role and tasks in defining aid for trade and trade facilitation. Ministers are not involved in shaping relations with other IOs. The emergence of the G-20, largely dominated by finance ministers, calls for a definition of the proper body and role for trade ministers to meet securing appropriate representation of the membership.

Executive boards would be composed of key trading nations with permanent seats. In addition, other states would be part of the board subject to a formula of participation on the basis of rotation, securing adequate geographical representation and representation of industrial, emerging, developing and least developing countries and existing coalitions. $^{24}$

From consensus towards qualified majorities. If IOs are not to become obsolete in the long run, they need to accommodate some form of qualified majority voting that goes beyond the one state, one vote formula. If the WTO system is not able to offer timely solutions to the existing challenges in the trading system, uncoordinated efforts to engage in forum-shopping will continue whereby states attempt to compensate for lack of outcomes. We observe in the context of the GATT/WTO regime that alternative regimes are again replacing the WTO in its liberalisation agenda, be it unilaterally, bilaterally or in the regional context. Yet, the lack of change is strongly related to existing mindsets of the trade diplomacy community. There is still a dominance of actors arguing for an international-national dichotomy, attributing to international politics a sui generis character rooted in realist thinking. Yet there is an argument to be made that governance layers are becoming increasingly blurred (Cottier 2009).

24 It could be envisaged that allowance would be made for different representations to the boards so that the composition of the $\mathrm{CB}$ and $\mathrm{MB}$ would not fully overlap. 
There are various forms and ways of taking recourse to voting. Different models could guide the development of a new design which offers an overall fair balance of rights and voting powers (Cottier and Takenoshita 2003, 2008). A norm that seems most likely to receive support in the long run and finds legitimisation in various philosophical conceptions of governance is a type of double majority. ${ }^{25} \mathrm{~A}$ simple model, as adopted in the EU Reform Treaty, would define the majority as being based on a qualified majority of states and a qualified majority of people who are affected by international trade rules, leaving other factors aside.

Yet the nature of the decisions may also affect the form of qualified majority to be applied. Not all decisions at an international level have similar repercussions in the domestic context, whether the WTO elects a new D-G, deliberates on the research agenda of the institution, manages the organisation's budget or agrees on stringent rules of intellectual property rights in new areas. There should be another effort to reflect on the potentials created by voting majorities that are defined by policy issues and their degree of societal intrusiveness. A new system should strive to find a more suitable match of substance and decision-making structure. Developing a doctrine of primary and secondary sources of WTO law would allow the definition of different avenues of decisionmaking, ranging from consensus on a few fundamentals of the system to qualified majorities for adopting and implementing rules. It would allow a distinction to be made between work within and outside trade rounds (Cottier 2010).

Streamlining decision-making processes. Alongside the strengthening of supranational elements and the selected application and use of majority voting systems, overall processes need to be more clearly defined and decision-making processes streamlined. Various existing committees continue to serve as platforms for agenda-setting, information exchange, deliberation and negotiations. Broad participation would allow for various ideas and positions to be advocated reflecting variance of interests among the existing membership. Timelines are needed for the elaboration of new rules and regulations. In particular, when issues get blocked there should be a quasi-automatic mechanism to refer the issue to the executive boards, first the $\mathrm{CB}$ and then the $\mathrm{MB}$, if no agreement is possible. Over time, the committees would have two functions. In the early stage of

25 Other models can be developed, taking into account factors such as shares in international trade, openness to trade and population size (Cottier and Takenoshita 2003). 
regulation, they would develop and narrow the scope and content of future regulation and later they would transform into decision bodies where they would deliberate suggest treaty texts and, at a defined stage, accept or reject proposals. This will allow the definition of a regulatory time frame within which new issues are to be addressed (with some flexibility to allow for rejections and revisions of proposed treaty texts). The General Council (composed of ambassadors or ministers) would meet periodically to assess progress, exchange views and adopt or reject proposals that are produced by different negotiating bodies.

Moving beyond the single undertaking. The idea behind the move towards more issue-specific rule-making is nurtured by the demand for issues to be addressed more quickly. Trade governance in the twenty-first century cannot wait for a round to be concluded before a pressing issue can be tackled that was not already on the agenda at the onset of that round. In order to address the danger that lack of linkages will block progress, the system should still rely on types of horse-trading at the level of the Board, or subsequently at the Ministerial level. It could also be worth considering the idea of mini rounds. More frequent Ministerial meetings at shorter intervals should help create a more common understanding of the challenges awaiting the trading system and the creation of a managing or executive board (see Scenario 2 above) under the chairmanship of the D-G should assist in elaborating timely answers. In addition, if issue-specific rule-making based on a new design of decisionmaking should prove difficult, the option of variable geometry (or what has been called more recently 'critical mass') should be available for actors without too onerous conditions attached (Low 2009; Elsig 2010a).

In addition, the idea of graduation should be further explored (Cottier 2006). Differential rights and obligations essentially emanate from the philosophy of progressive liberalisation in GATT and GATS, but new Agreements, such as the TRIPS Agreement, have adopted essentially uniform standards of protection for all members alike. Ways and means to transform the idea of progressive and individualised liberalisation into the realm of uniform regulation of non-tariff barriers should be sought. Instead of particular provisions and exemptions for developing and least developed countries, the suggestion is to combine single standard rules with economic factors and indicators reflecting the competitiveness of a sector or economy. These factors and indicators will determine whether to trigger the application of the rule and discipline at hand. Prior to this, members would not be subject to it. This approach brings about graduation in terms of legal obligations, commensurate with the level of 
competitiveness. ${ }^{26}$ The difficulty and challenge will be to find and agree upon appropriate indicators. Economists are called upon to develop them in coming years.

Supply side support. Finally, what we have learned from EU integration is that the creation of more integrated markets also calls for additional auxiliary instruments to support weaker states. Given unequal national and regional starting points, efforts have been made through infrastructure projects and other types of welfare transfer to allow weaker actors to benefit from the single market. In the context of the WTO, general welfare transfer seems too ambitious, yet initiatives that address supplyside constraints to the successful use of the existing system need to be strengthened and cooperation with other IOs intensified (see Chapter 9). The current discussions on mainstreaming trade facilitation into the WTO system and the aid for trade agenda both link the trade and development communities in novel ways. The outcomes of this newly found interest in the trade-development link will provide us with important information as to the potentials for designing new support schemes.

\section{Conclusion}

Today's international politics (in particular outside the realm of old security issues) bears less and less resemblance to the classical billiard ball model of nation states as advocated by realist scholars in the past (mostly on a false presumption in Westphalian terms) (Waltz 1979). The system today more closely resembles a spider's web model of interdependence (Nye and Keohane 1977) directing global governance towards new prerogatives of an emerging Weltinnenpolitik. This calls for more than a system of governance without government as some of the early global governance literature suggests, but puts IOs right back into the spotlight of governance.

In terms of reform, how realistic are the above suggestions in light of the 'stickiness of institutions' and the inherent interests of decisionmakers in locking-in existing rules? Is anything other than incremental change possible? It is clear that delegation of powers within the WTO requires a firmer constitutional framework. The scenario outlined above is meant to provide impetus to ongoing debates on the redesign of WTO

26 Importantly, it would allow the existing advantages of single undertaking (as all legal instruments are binding for all members) to be combined with the flexibility of variable geometry (within agreements, thresholds bring about differential obligations). 
decision-making. What might seem far-fetched and naïve today could be labelled realistic and necessary in the years to come. Who would have thought that states would give up their veto powers in relation to accepting the creation of panels and the adoption of panel reports at the onset of the UR negotiations? One necessary condition of a successful redesign of the DSU was the existence of a majority view among members that the panel system was dysfunctional and that something had to be done. The current experience with the negotiation machinery has left many members dissatisfied, opening up the opportunity to discuss additional steps of delegation and new decision rules that have the potential to address the incompatibility of the existing triangle of decision-making.

\section{References}

Alter, Karen 1998. 'Who are the "masters of the treaty"?: European governments and the European Court of Justice', International Organization 52(1): 121-47.

Barfield, Claude 2001. Free Trade, Sovereignty, Democracy: the Future of the World Trade Organization. Washington, DC: AEI Press.

Blackhurst, Richard 1998. 'The capacity of the WTO to fulfill its mandate', in Anne Krueger (ed.), The WTO as an International Organization. University of Chicago Press, pp. 31-58.

Cottier, Thomas 2006. 'From progressive liberalization to progressive regulation in WTO law', Journal of International Economic Law 9(9): 779-821.

Cottier, Thomas 2007. 'Preparing for structural reform in the WTO', Journal of International Economic Law 10(3): 497-508.

Cottier, Thomas 2009. 'The legitimacy of WTO law', in Linda Yueh (ed.), The Law and Economics of Globalization. Cheltenham: Edward Elgar, pp. 11-48.

Cottier, Thomas 2010. 'A two-tier approach to WTO decision-making', in Debra Steger (ed.), Redesigning the World Trade Organization for the Twenty-First Century. Waterloo: Wilfrid Laurier University Press, CIGI and IDRC, pp. 43-66.

Cottier, Thomas and Takenoshita, Satoko 2003. 'The balance of power in WTO decision-making: towards weighted voting in legislative response', Aussenwirtschaft 58(2): 171-214.

Cottier, Thomas and Takenoshita, Satoko 2008. 'Decision-making and the balance of power in WTO negotiations: towards supplementary weighted voting', in Stefan Griller (ed.), At the Crossroads: the World Trading System and the Doha Round. New York: Springer, pp. 181-230.

Croome, John 1995. Reshaping the World Trading System. Geneva: WTO.

Dahl, Robert 1999. 'Can international organizations be democratic? A skeptic's view', in Ian Shapiro and Casiano Hacker-Cordón (eds.), Democracy's Edges. New York: Cambridge University Press, pp. 19-36. 
Drezner, Daniel 2007. All Politics is Global. Princeton University Press.

Ehlermann, Claus-Dieter and Ehring, Lothar 2004. 'Decision-making in the World Trade Organization', Journal of International Economic Law 8(1): $51-75$.

Elsig, Manfred 2007. 'The World Trade Organization's legitimacy crisis: what does the beast look like?', Journal of World Trade 41(1): 75-98.

Elsig, Manfred 2009a. 'The World Trade Organization at work: performance in a member-driven milieu', Paper presented at the ISA, New York, 15-18 February.

Elsig, Manfred 2009b. 'The EU in the Doha negotiations: a conflicted sponsor?', in Amrita Narlikar and Brendan Vickers (eds.), Leadership and Change in the Doha Negotiations. Leiden: Brill/Martinus Nijhoff, pp. 23-43.

Elsig, Manfred 2010a. 'WTO decision-making: can we get a little help from the secretariat and the critical mass?', in Debra Steger (ed.), Redesigning the World Trade Organization for the Twenty-First Century. Waterloo: Wilfrid Laurier University Press, CIGI and IDRC, pp. 67-90.

Elsig, Manfred 2010b. 'Principal-agent theory and the WTO: complex agency and "missing delegation"', European Journal of International Relations in press.

Fearon, James 1998. 'Bargaining, enforcement and international cooperation', International Organization 52(2): 269-305.

Finnemore, Martha and Sikkink, Kathryn 1998. 'International norms and political change', International Organization 52(4): 887-917.

Footer, Mary 2006. An Institutional and Normative Analysis of the World Trade Organization. Leiden: Martinus Nijhoff.

Goldstein, Judith and Martin, Lisa 2000. 'Legalization, trade liberalization and domestic politics: a cautionary note', International Organization 54(3): 603-32.

Grant, Ruth and Keohane, Robert 2005. 'Accountability and abuses of power in world politics', American Political Science Review 99(1): 29-43.

Gruber, Lloyd 2000. Ruling the World: Power Politics and the Rise of Supranational Institutions. Princeton University Press.

Gutner, Tamar and Thompson, Alexander 2008. 'Explaining IO performance: an initial framework', Paper presented at the ISA Venture Research Workshop, San Francisco, 25 March.

Jackson, John 2001. 'The WTO "Constitution" and proposed reforms: seven mantras revisited', Journal of International Economic Law 4(1): 67-78.

Krasner, Stephen 1999. Sovereignty: Organized Hypocrisy. Princeton University Press.

Low, Patrick 2009. 'WTO decision-making for the future', Paper presented at the inaugural conference of TAIT (Thinking Ahead on International Trade): Challenges Facing the World Trade System, World Trade Organization, Geneva, 17-18 September. 
March, James and Olsen, Johan 2009. 'The logic of appropriateness', Arena Working Papers WP 04/09.

Narlikar, Amrita 2003 International Trade and Developing Countries: Coalitions in the GATT and WTO. London: Routledge.

Nye, Joseph and Keohane, Robert 1977. Power and Interdependence: World Politics in Transition. Boston: Little, Brown and Company.

Odell, John 2005. 'Chairing a WTO negotiation', Journal of International Economic Law 8(2): 425-48.

Putnam, Robert 1988. 'Diplomacy and domestic politics: the logic of two-level games.' International Organization 42(3): 427-60.

Steger, Debra 2010. Why institutional reform of the WTO is necessary, in DebraSteger (ed.), Redesigning the World Trade Organization for the Twenty-First Century. Waterloo: Wilfrid Laurier University Press, CIGI and IDRC, pp. 3-10.

Steger, Debra and Shpilkovskaya, Natalia 2010. 'Internal management of the WTO: room for improvement', in Debra Steger (ed.), Redesigning the World Trade Organization for the Twenty-First Century. Waterloo: Wilfrid Laurier University Press, CIGI and IDRC, pp. 129-61.

Steinberg, Richard 2002. 'In the shadow of law or power? Consensus-based bargaining and outcomes in the GATT/WTO', International Organization 56(2): 339-74.

Tallberg, Jonas 2010. 'The power of the chair: formal leadership in international cooperation', International Studies Quarterly 54(1): 241-65.

Van den Bossche, Peter 2006. 'From afterthought to centrepiece: the WTO Appellate Body and its rise to prominence in the world trading system', in Giorgio Sacerdoti, Alan Yanovich, and Jan Bohanes (eds.), The WTO at Ten. Cambridge University Press, pp. 289-325.

VanGrasstek, Craig and Sauvé, Pierre 2006. 'The consistency of the WTO rules: can the single undertaking be squared with variable geometry?', Journal of International Economic Law 9(4): 837-64.

Waltz, Kenneth 1979. Theory of International Politics. Reading, MA: AddisonWesley.

Warwick Commission 2007. The Multilateral Trade Regime: Which Way Forward? The University of Warwick.

Wilkinson, Rorden 2009. 'Power, performance and the WTO', Paper presented at the International Studies Association Annual Convention, New York, USA, 15-18 February.

Winham, Gilbert 1986. International Trade and the Tokyo Round Negotiation. Princeton University Press.

$\mathrm{Xu}$, Yi-chong and Weller, Patrick 2004. The Governance of World Trade: International Civil Servants and the GATT/WTO. Cheltenham: Edward Elgar. 